\title{
Naturaleza y Justicia de los contratos administrativos
}

\section{Nature and Justice of Government contracts}

Jaime Arancibia Mattar

El presente artículo aborda la naturaleza y justicia del contrato administrativo. Sostiene que no es un contrato sino un acto administrativo mixto y modal de imposición de cargas públicas compensadas cuyos efectos están sujetos a la aceptación del destinatario. Por tanto, la relación jurídica no se perfecciona en virtud de un acuerdo de voluntades sino del acto administrativo que adjudica de dicha carga. La justicia que rige el contrato es distributiva, que es la propia de las relaciones entre el titular del interés del todo y una de sus partes surgidas a partir de actos unilaterales, potestativos y distributivos.

Palabras clave: contrato, administrativo, unilateral, justicia, distributiva.
This article deals with the nature and justice of government contracts. It argues that it is not a contract but a mixed and modal administrative decision that imposes public compensated burdens whose effects are subject to the acceptance by the addressee. Therefore, the legal relationship is not perfected by an agreement but by the administrative decision that awards such burden. Public contracts are subject to distributive justice, which is inherent to any legal relationship between the community as a whole and a person as one of its parts.

Keywords: contract, government, nature, unilateral, distributive.

\section{Introducción}

El presente artículo aborda la naturaleza y justicia de los contratos administrativos. Sostenemos que son actos administrativos regidos por la justicia distributiva y no acuerdos sometidos a la justicia conmutativa. Solo así es posible comprender a cabalidad sus atributos diferenciadores con el contrato privado. Puesto que son actos administrativos, el

\footnotetext{
* Profesor de Derecho Administrativo, Universidad de los Andes, Chile. Dirección Postal: Mons. Álvaro del Portillo 12.455, Las Condes, Santiago de Chile. Correo electrónico: jarancibia@uandes.cl. Este artículo fue escrito en el marco del Proyecto Fondecyt Regular, № 1181593, sobre "La potestad de autorización administrativa: fundamentos dogmáticos, régimen y problemas en el ordenamiento jurídico chileno" en el que el autor es investigador responsable.

Recibido el 29 de octubre de 2019 y aceptado el 10 de diciembre de 2019.
} 
origen de la relación jurídica es unilateral y potestativo y no bilateral y consensual; el fundamento del equilibrio económico de las partes no es la justicia conmutativa -como en los contratos entre privados- sino distributiva, y la vigencia del equilibrio económico no está condicionada a su reconocimiento legal o contractual, sino que es exigida directamente por la Constitución en virtud del imperativo de igualdad ante los bienes y cargas públicas (art. 19 $\mathrm{N}^{\circ} 2$ y $\mathrm{N}^{\circ} 20$ ).

El reconocimiento de estos atributos determina que la imposición de encargos compensados esté sujeta a un régimen de rebus sic stantibus que exige ejercer poderes legales de modificación o extinción ${ }^{1}$ del contrato cada vez que los componentes indisolubles del bien común, interés público y privado, de todos y de cada $u_{n o}^{2}$, se vean afectados ${ }^{3}$. Por eso que el Estado no podría regirse por la doctrina de los actos propios ${ }^{4}$. Cuando el bien común lo exige, el Estado no solo puede sino debe volver sobre sus propios actos. En este sentido, Vásquez de Menchaca sostuvo en el siglo XVI que el príncipe es legibus solutus o libre de leyes no porque puede desobedecerlas sino porque "puede suprimirlas para bien de la república"5. Aplicando esta idea a los contratos, Suárez sostuvo en el siglo XVII que si bien el príncipe "está obligado a cumplir los pactos -aun los hechos con súbditos suyos-, dado que esta obligación nace de la justicia natural", "también podrá revocar el privilegio a pesar del contrato"6.

Sin embargo, el propio bien común condiciona esta mutación al respeto del segundo de sus componentes: los derechos adquiridos e intereses del particular de buena fe. En palabras del mismo Suárez, "aunque el príncipe -por una necesidad pública o por otra causa urgente- pueda rescindir el contrato, pero no puede en justicia privar completamente al súbdito de lo suyo sin una compensación: esto no es necesario para el bien común, y el súbdito no está obligado a ceder de su derecho gratuitamente cuando puede dársele una compensación, dado que el príncipe no es dueño absoluto de las cosas del súbdito"7.

Para efectos de desarrollar las ideas anteriores, este trabajo se dividirá en dos secciones. La primera abordará la naturaleza del contrato como acto administrativo mixto y modal. Sobre esta base, la segunda explicará que dicho acto está regido por la justicia distributiva, que asegura el equilibrio financiero de las partes en razón del principio de igualdad ante los bienes y cargas públicas.

\footnotetext{
1 En obra pública, véase Alfredo León Ramírez con I. Municipalidad de Quillota (2009).

2 Art. 1 inciso $4^{\circ}$ de la Constitución.

3 En materia de obra pública, esta idea ya aparece expresada en el fallo del Consejo de Estado en el caso de Francisco Ovalle (1856), sobre construcción de los almacenes fiscales de Valparaíso.

4 Para una explicación del concepto véase, Corral 2010, 19 a 33.

5 Vasquez de Menchaca 1564, 133.

6 SUÁREZ 1968, 1062.

7 ldem.
} 


\section{Naturaleza de los (mal llamados) contratos administrativos}

Las prestaciones voluntarias y compensadas de los particulares al Estado suelen recibir la denominación y tratamiento de "contratos". Dado que se observa un intercambio "consentido", resulta difícil no calificarlo como acuerdo o pacto, sobre todo considerando la fuerza dogmática de la institución contractual a lo largo de la historia. A esta conclusión llegaron Laband ${ }^{8}$ y Kelsen ${ }^{9}$ en Alemania hace un siglo, sobre la base de un concepto amplio de contrato; y así concluye también la doctrina europea ${ }^{10}$ y nacional ${ }^{11}$ prácticamente sin excepciones ${ }^{12}$. Posiblemente, esta práctica se debe a la inclinación natural de la razón humana a identificar ciertas realidades con el concepto que les resulte más familiar o conocido, es decir, una especie de sesgo cognitivo propio de la heurística de la representatividad ${ }^{13}$.

Luego de asignada esta calificación contractual, sin embargo, su coherencia dogmática comienza a tambalear ante la entidad y número de diferencias que presenta con los contratos privados. Se dice, en primer lugar, que la autonomía de la voluntad está severamente limitada por un estatuto contractual previo que obliga a elegir al contratista por concurso público, impide alteraciones sustantivas, exige mantener la equivalencia de las prestaciones recíprocas y compensar al contratista por desequilibrios financieros causados incluso por órganos distintos al contratante. Además, la nulidad del contrato protege la confianza legítima del adjudicatario de buena fe, y los intereses sustentados por las partes son desiguales, es decir, guardan una relación de verticalidad entre ellos. Por lo mismo, el mandante estatal ejerce poderes unilaterales de dirección, interpretación, control, sanción, secuestro, modificación y extinción del contrato. Se exceptúa así de la regla áurea del artículo 1545 del Código Civil.

Estos atributos se manifiestan incluso en los contratos administrativos de raigambre anglosajona. En este caso, el camino de la inconsistencia es aún más largo. Se inicia con la declaración de que están regidos por el derecho privado ${ }^{14}$, para luego terminar reconociendo atributos naturales de una relación jurídica pública por vía legal ${ }^{15} \circ$ administrativa a través de pliegos

\footnotetext{
8 LABAND 1876.

9 KeLSEN 1913, 53-98, y 190-249, especialmente 225 y ss.

10 Loo 2018, 129-155; Dicey 1915, 107-122.

11 Pantoja 1994, 65-66; Silva 2001, 174; Moraga 2007, 21; Soto 2012 547-564; Bermúdez 2014, 239; Cordero 2015, 442; VAldivia 2018, 300-201. A nivel de artículos doctrinarios, véase OelCKERS 1979, 143. Una realidad similar se aprecia en la noción de contrato administrativo en el siglo XIX. BoCKSANG 2015, 632-700.

12 Podemos mencionar como excepción los trabajos de MAYer 1888, 3-86; RANelletti 1945, 139 y ss.; y LÓPEZ 1998, 947-969.

13 Kanemman y TVersky 1974, 1124-1131.

14 En Estados Unidos véase tempranamente el caso Cooke v. United States, 91 U. S. 389.

15 Por ejemplo, en cuanto al origen legal de la potesdad para contratar, véase HAYNE 2017, pp. 155 a 181. Ver también, TROWBRIDGE VOM BAUR, 1967, 248.
} 
de condiciones y cláusulas de ajustes contractuales ${ }^{16}$; o simplemente en virtud de los principios que prohíben a la Administración Pública discriminar arbitrariamente ${ }^{17}$, infringir el debido proceso ${ }^{18}$, o comprometerse a no alterar los términos de la relación ante circunstancias futuras que puedan afectar el interés público (no-fettering, unfettering discretion o non-estoppel) ${ }^{19}$. En este sentido, se ha señalado que "precisamente porque los contratos administrativos reflejan una relación de poder, y no un acuerdo consensual entre iguales, es que condiciones obligatorias pueden ser adjuntadas a ellos" 20 .

Por regla general, la doctrina ha procurado justificar estas diferencias recurriendo a explicaciones que, a nuestro juicio, eluden el problema de fondo. Por un lado, pese a su relevancia sustantiva, se sostiene que se trata simplemente de "excepciones", "cláusulas exorbitantes", o de "privilegios" contractuales de la Administración en razón del interés público que resguardan. No faltan tampoco los que pretenden negar el carácter excepcional o privilegiado de la sanción, caducidad, invalidación e interpretación administrativa del contrato atribuyendo al órgano competente el carácter adicional de juez ${ }^{21}$. Por otro lado, el contrato administrativo ha sido calificado como "híbrido", sui generis 22 , ius singularis, "supraconcepto"23, o "mandato".

Sin embargo, cual zapato perdido de la Cenicienta, el contrato administrativo no parece calzar cómodamente con ninguno de estos moldes. Cuando una institución jurídica es exceptuada de la mayoría de sus atributos típicos, su identificación conceptual ha sido probablemente errónea. Este sería, precisamente, el caso de los mal llamados contratos administrativos. Siguiendo con nuestra analogía, en nuestra opinión, la Cenicienta con que la figura del contrato "calzará" perfectamente es el acto administrativo.

\footnotetext{
16 Por ejemplo, "changed conditions clause", "suspension of work clause", "modified changes clause". Cfr. Cuneo y CROWell 1964, 153 y ss. Considérese también la cláusula de término unilateral de un "contrato" de licencia en Inglaterra, que fue objeto de litigio en R. v. Barnsley Metropolitan Borough Council (1976); en R. v. Basildon District Council (1981); y en R. v. Wear Valley District Council (1985). Y la cláusula de término de concesión de inmuebles públicos, objeto de litigio en Cannock Chase D. C. v. Kelly (1978). Para Estados Unidos, ver MeWett (1958). 238.

17 Véase la sentencia en el caso R. v. Lewisham Borough Council (1988).

18 R.v. Enfield London Borough Council (1989).

19 Véase el fallo en el caso Rederiaktiebolaget Amphitrite v. The King (1921), en que el juez Rowlatt declaró que "El Gobierno no puede por contrato obstaculizar su libertad de acción en materias que conciernen el bienestar del Estado". La traducción es nuestra. Codina 2014, 426. Para Estados Unidos, véase el fallo de la Corte Suprema en Contributors to Pennsylvania Hospital v. Philadelphia (1917), sobre "contrato" de expropiación.

20 Miller 1955, 57.

21 Nos referimos a la doctrina del "Ministro-juez" que nace en Francia de la mano de Cormenin y se extiende luego a España. Cfr. PARAdA 1963, 168 a 182.

22 Bacellar 2014, 53.

23 Meilán 2015, 229.
} 


\section{El contrato administrativo es un acto administrativo mixto y modal}

Siguiendo en parte la argumentación de Mayer24, Hauriou ${ }^{25}$, Laubadere ${ }^{26}$, Forsthoff ${ }^{27}$ y López Muñiz ${ }^{28}$, entre otros, los contratos administrativos entre el Estado y los miembros de la comunidad a la que sirve ${ }^{29}$ no revisten una naturaleza contractual. Se trata más bien de actos jurídicos unilaterales de imposición ${ }^{30}$, asignación o distribución de cargas públicas compensadas o mixtos cuyos efectos están sujetos a la aceptación del destinatario, ad voluntatem privatis. En efecto, la relación jurídica no se perfecciona en virtud de un acuerdo de voluntades sino del acto administrativo que adjudica de dicha carga conforme a un estatuto previo que la rige o lex statutus, para diferenciarla a así de la lex contractus.

Por tanto, la aceptación del encargo por el particular no tiene por función dar origen a una relación jurídica con la Administración sino simplemente que esta produzca efectos; es, por tanto, condición de ejecutoriedad o eficacia y no de existencia de la misma. Podemos sostener así que el acto adjudicatorio de la carga es modal, pues sus efectos están sujetos a la condición suspensiva de aceptación del particular. Las obligaciones recíprocas se hacen exigibles, entonces, ante la convergencia de dos actos jurídicos unilaterales: imposición y aceptación de una carga pública compensada. Como explica Ducci "No obsta al carácter unilateral de un acto el que posteriormente para producir efectos necesite el que haya otra manifestación de voluntad"31. Por ende, en la práctica, cuando el particular "suscribe" o "firma" un contrato ya adjudicado, no lo está perfeccionando sino dotando de eficacia.

En igual sentido, Laubadere explica que, según la jurisprudencia francesa, "el acuerdo dado al acto por su destinatario no tiene como consecuencia que se produzca un contrato, ni siquiera de manera más general un acto bilateral, incluso aunque el acuerdo vaya acompañado de un compromiso del destinatario del acto... La jurisprudencia reconoce la existencia de actos unilaterales tomados 'con el acuerdo' del destinatario (o 'en acuerdo' con él); de manera general, ella admite que un acto unilateral solicitado o aceptado no deviene necesariamente en un contrato" 32 .

\footnotetext{
24 MAYER 1888, especialmente 23 a 26, 39.

25 HaURIOU, 1916, 136 y ss.

26 LAUBADERE 1956, 50 y ss.

27 FORSTHOFF 1969, 333 y ss.

28 LÓPEZ 1998, 947-969. Ver también López 2010, 41 a 65.

29 Para diferenciarlos así de los contratos suscritos con el Estado con otros estados o empresas extranjeras, en que la naturaleza de la relación sí sería contractual.

30 Utilizamos el vocablo "imposición" en su sentido más genuino, esto es, "acción y efecto de imponer o imponerse", entendiendo por imponer "poner una carga, una obligación u otra cosa". Real Academia Española 2001.

31 DUCCI 2005, 236.

32 LAUBADERE et al. 1983, 59-60. La traducción es nuestra.
} 
Cabe enfatizar que siempre estamos en presencia de un procedimiento administrativo contractual, sea o no concursal o licitatorio. El acto terminal del procedimiento es la adjudicación del contrato. Como todo acto administrativo terminal, su ejecutoriedad, eficacia o producción de efectos puede ocurrir a partir de su notificación (ejecutoriedad propia) o con posterioridad a ella (ejecutoriedad impropia) ${ }^{33}$. Al respecto, la ley $N^{0} 19.880$ establece que "[l]os actos de la Administración Pública sujetos al Derecho Administrativo causan inmediata ejecutoriedad, salvo en aquellos casos en que una disposición establezca lo contrario..." (art. 51). Este último es el caso de los actos adjudicatorios contractuales, que requieren la aceptación del particular para producir efectos; a menos que la ley estime que dicha aceptación se produjo en virtud de un acto trámite anterior (v.gr. postulación, solicitud, etc.), en cuyo caso el acto adjudicatorio sería de ejecutoriedad propia.

A mayor abundamiento, Hauriou sostiene que la aceptación del destinatario constituye una forma ejecutoria del acto disociada del acto anterior: "estos actos sucesivos son decisiones, pero no hay fusión subjetiva de consentimientos, ya que cada una de las decisiones se junta con las precedentes, para adherirse, una vez que estas no están en el estado de actos sino de hechos: ya no contienen la voluntad en fusión, sino la voluntad solidificada para que se lleve a cabo. No hay concurrencia de consentimientos para el mismo acto subjetivo, pero se incorporan nuevos consentimientos a los antiguos, mediante el acceso al mismo procedimiento, que es un acto jurídico objetivo" ${ }^{34}$.

Esta tesis contradice la pretensión de "fusionar" los actos unilaterales de adjudicación y aceptación del contrato para transformarlos en un solo acuerdo de voluntades subjetivas al estilo del contrato privado. Bajo esta lógica, todo acto condicionado a la aceptación del destinatario sería un contrato, como aquellos de nombramiento, permiso, concesión, elección popular, etc., lo que ciertamente resulta artificioso. De existir un "acuerdo", este no es "celebrado" entre partes sino "prestado" por una parte al acto autosuficiente de la otra ${ }^{35}$, en el sentido de su segunda acepción en el diccionario: "resolución premeditada de una sola persona..." 36 .

Esta realidad es inherente a las relaciones jurídicas estatutarias, en que la aceptación del sujeto conlleva la adquisición de un status ${ }^{37}$, posición o condición jurídica particular regida por un statutum. Explica Alessandri que no es

\footnotetext{
33 No debe confundirse la ejecutoriedad del acto, referida al momento en que produce efectos, con su ejecutividad, relativa a la exigibilidad de estos. La ejecutividad se predica respecto de un acto ejecutoriado cuyos efectos pueden estar vigentes o suspendidos y, por tanto, ser inexigibles. La jurisprudencia de la Corte Suprema ha incurrido en confusiones al respecto. Cfr. Fisco de Chile con Dorr Zegers María Teresa y otros (2014), c. $11^{\circ}$ y ss., Fisco de Chile con Vicente Aresti López y otros (2016), c. 12. Una distinción correcta se observa en Empresa de Servicios Himce Limitada con Municipalidad de Hualqui (2017), c. $7^{\circ}$.

34 HaURIOU 1916, 146. La traducción es nuestra.

35 LAUBADERE et al. 1983, 59.

36 Real Academia Española 2001. La cursiva es nuestra.

37 Cfr. HiRsChfeld 1902, 168-172.
} 
un derecho subjetivo sino una "situación-base... un presupuesto de relaciones jurídicas, de derechos y deberes... Es una cualidad jurídica del individuo que denota la posición que tiene en una colectividad humana" 38 , como el estado civil. En este caso, el status adquirido es el de contratista del Estado, sujeto al estatuto público respectivo. La palabra es connatural, además, a la expresión stato, utilizada por Maquiavelo en su Príncipe para referirse a la organización política moderna, es decir, el Estado como orden jurídico "estatuido"39.

En este sentido, el vínculo jurídico asumido por un contratista con el Estado es sustancialmente similar al de un funcionario público, incluso en su ritualidad, que Hauriou describe como "solicitud [de carga] aceptada" 40. Rememora los actos unilaterales convergentes de la antigua institución de la commendatio ${ }^{41}$ : manifestación de interés en servir, imposición del encargo, y juramento o promesa para que produzca efectos. Y si tuviéramos que asociar esta figura a una institución de derecho privado, la respuesta no sería el contrato, ni siquiera de adhesión, sino aquellas de origen unilateral como la aceptación de una herencia o legado, la donación, o la stipulatio romana ${ }^{42}$. En resumen, como lúcidamente señaló Desjardins, "no es posible hablar propiamente de 'contratos administrativos', porque semejante adjetivo no puede ir acompañado de semejante sustantivo" 43 .

Esta realidad hunde sus raíces en los atributos de la relación jurídica pública que, a diferencia de la privada, solo puede tener su origen en actos unilaterales de distribución de cargas o beneficios al interior de la comunidad. Esta distribución se ejerce a través de actos potestativos o de puissance publique ${ }^{44}$ que tienen por finalidad la satisfacción del bien común. $Y$ es que por su propia naturaleza el Estado no puede mantener relaciones jurídicas de igualdad con aquellos respecto de los cuales es ontológicamente desigual en relación con sus intereses y fines. La autoridad política existe para servir a los integrantes de la comunidad mediante una actividad de reparto vertical y no de conmutación horizontal, pues esta última es connatural a sujetos con intereses equivalentes. El interés del Estado, en cambio, será siempre desigual, superior y omnicomprensivo porque busca el bien de todos y de cada uno. Su actividad es esencialmente supraordenadora, no equiordenadora ${ }^{45}$, y por eso se rige por la mutabilidad del rebus sic stantibus, no por la rigidez del acta o promissa sunt servanda, sin perjuicio de las compensaciones a que haya lugar.

\footnotetext{
38 Alessandri et al. 1999, 299.

39 Maquiavelo 1998, 130.

40 HaURIOU 1933, 743.

41 BLOCH 1968, 162.

42 D'ORS 1980, 316-320.

43 MAYER 1888, 25.

44 Siguiendo la nomenclatura de HAURIOU 1900, 227.

45 Por eso que resulta cuestionable la definición de contrato administrativo del Dictamen $N^{\circ} 46.532$ (2000), como aquel en que la Administración actúa "en un plano de igualdad con los particulares".
} 
Estos fundamentos permiten descartar incluso el carácter contractual de los intercambios público-privados regidos por la legislación civil, laboral o comercial (v.gr. compraventa, permuta, cesión de derechos, sociedad, arrendamiento, prestación de servicios, trabajo). Tales relaciones son igualmente actos de autoridad de origen unilateral, potestativos, distributivos de bienes y cargas, y con fines públicos de fomento, empresa o servicio estatal; solo que la regulación de las prestaciones mutuas es remitida a la legislación privada. Esta derivación no transforma la relación en un acuerdo privado, por la misma razón que un acuerdo laboral entre particulares que se remita al Estatuto Administrativo no da origen a un empleo público. Lo relevante para estos efectos no es el estatuto prestacional sino las partes, intereses y origen de la relación, incluso a falta de potestades exorbitantes.

Cualquier relación jurídica del Estado con los particulares gozará siempre de atributos ajenos a la figura contractual, aunque el régimen de obligaciones se remita al derecho privado y esté sometido a la jurisdicción común. Desde luego, porque la norma privada es solo una porción del bloque jurídico que rige la relación, compuesto además por normas constitucionales y legales sobre requisitos, límites jurídicos, y régimen de impugnación de las atribuciones contractuales. Estos preceptos constituyen un verdadero "régimen" o "atmósfera" de derecho público, como diría Weil ${ }^{46}$, siempre presentes en un intercambio público-privado para asegurar la vigencia del bien común con pleno respeto de los derechos.

Por estas razones, no compartimos la doctrina y jurisprudencia francesa que desde fines del siglo XIX distingue entre contratos "administrativos" y "privados" de la Administración dependiendo de si conceden o no un servicio público ${ }^{47}$. Este criterio reduce lo administrativo a la actividad prestacional del Estado, olvidando que la finalidad de los contratos regidos en parte por normas de derecho privado es también esencialmente administrativa y de interés público, como el fomento de actividades privadas, el Estado empresario o la organización administrativa. Bajo esta perspectiva finalista o funcional, todo contrato celebrado por la Administración es intrínsecamente administrativo y jamás privado, con prescindencia de las normas que rigen el intercambio obligacional. El Estado, cual rey Midas, publifica todo lo que toca en razón de su fin. Negar la naturaleza pública de un contrato de la Administración regido parcialmente por la legislación privada equivale a negar que el fin esencial y último de todo acto estatal es asegurar el bien común.

Tampoco cabría distinguir entre contrato privado y administrativo dependiendo de si la autoridad cuenta o no con poderes exorbitantes del derecho común. Si aceptamos que todo contrato administrativo tiene su origen en un acto unilateral, siempre contará al menos con esa exorbitancia, descartando por tanto toda posibilidad de estar íntegramente regido por la legis-

\footnotetext{
46 WEIL 2016, 182-183.

47 JÈZE 1927, 7-9.
} 
lación privada. Lo anterior es sin perjuicio, además, de otros poderes que el legislador pueda atribuir de modo específico o genérico para mantener los efectos del acto sometidos al bien común.

\section{Críticas y defensas a la tesis del contrato administrativo como acto potestativo mixto}

No obstante lo expuesto, la conceptualización del contrato administrativo como acto unilateral no ha estado exenta de críticas. Podemos citar, en primer lugar, la opinión de Ariño Ortiz, para quien esta noción sería errónea, en primer lugar, porque el acto carece de la fuerza de ley que tienen los contratos administrativos, esto es, "una vez que se ha producido el acuerdo de voluntades y ha nacido el contrato, este tiene prevalencia sobre las normas legales" 48 .

Sin embargo, este argumento parece inapropiado para desvirtuar la naturaleza unilateral del acto, porque esta se refiere al origen de la relación jurídica y de sus efectos, no al régimen aplicable una vez vigente. Por tanto, es preciso centrar el análisis en el hecho que causa la relación y no en el estatuto que la rige. No basta con sostener que el contrato administrativo es contrato porque tiene fuerza de ley, pues eso equivale a decir que es contrato simplemente porque es tratado como tal. Además, nada obsta a que una relación jurídica de origen unilateral pueda gozar de una estabilidad equivalente a la de un contrato, por el solo ministerio de la ley, sin perder su unilateralidad.

Otra crítica, sostenida por la doctrina alemana ${ }^{49}$ y en España por autores como Ariño Ortiz ${ }^{50}$, Meilán Gil ${ }^{51}$ y Barra ${ }^{52}$, sostiene que la tesis unilateral no resulta aplicable a casos donde el estatuto es negociado previamente entre la Administración y el particular, de modo que las obligaciones recíprocas son causa la una de la otra porque ha existido un acuerdo de voluntades. En palabras de Meilán, la voluntad del particular en tales casos "contribuye a la formación del contenido del contrato, forma parte del supuesto de hecho en que se va a concretar la norma... es condición de validez" ${ }^{\prime 53}$.

Sin embargo, en nuestra opinión, el supuesto consenso sobre el estatuto del contrato no da origen a relación contractual alguna, pues esta solo nacerá por un acto jurídico unilateral posterior a la aprobación, también unilateral, de aquel estatuto: la adjudicación. En este sentido, es acertado sostener que el asentimiento del particular a los términos contractuales puede constituir un supuesto de hecho previsto en la norma, solo que dicho supuesto revestiría el carácter de acto trámite esencial u obligatorio, de contenido vinculante o no vinculante, en el proceso de elaboración del estatuto

\footnotetext{
48 ARIÑO 2007, 88.

49 Resumida por Huergo 1998, 152.

50 ArIÑo 2007, 51.

51 MeILÁN 2015, 51.

52 BARRA 1989.

53 MeILÁN 2015.
} 
contractual ${ }^{54}$. Es posible también que este sea condición de validez, pero lo sería de la norma estatutaria y no de la relación jurídica que será regida por esta. Es posible incluso que a dicha manifestación de voluntad se le atribuya normativamente el efecto de aceptación anticipada de la carga pública, en cuyo caso sería condición de validez del estatuto contractual y condición de eficacia del acto adjudicatorio.

En consecuencia, incluso en casos de negociación del contrato entre el Estado y el particular, la aceptación de la carga pública es condición de eficacia y no de existencia o validez de la relación jurídica contractual. La causa de las prestaciones mutuas continúa siendo, por tanto, la adhesión unilateral a un estatuto previo de interés público. No existe el duorum in idem placitum consensus propio de los contratos.

Un tercer contraargumento, esbozado por Martin-Retortillo55, podría ser que la desigualdad de las partes no afecta la naturaleza contractual de la relación. Cita, a modo ejemplar, el contrato celebrado entre un esclavo, con dinero de su peculio, y un ciudadano romano. Y podríamos argüir en apoyo de esta crítica que el derecho moderno se ha preocupado, precisamente, de asegurar un equilibrio negocial entre contratantes desiguales en ámbitos donde el más fuerte podría aprovecharse del principio de autonomía de la voluntad, como en materia laboral o de derecho del consumidor ${ }^{56}$, a través de contratos de adhesión.

Sin embargo, la naturaleza peculiar de la relación contractual pública no se basa en la desigualdad negocial de las partes sino en la desigualdad de sus intereses, puesto que es un caso singular en que una de las partes de la relación (Estado) debe proteger el bien de todos, incluyendo el de su contraparte $^{57}$. Esta verticalidad de intereses no existe en la figura contractual, que supone de suyo una relación entre intereses de valoración jurídica equivalente, independiente de la capacidad negocial de las partes. Además, como acota Juristo Sánchez, la asimetría de las partes en derecho privado es siempre factual y repudiable, mientras que la del Estado con el particular es constitutiva y legítima por razones de bien común ${ }^{58}$.

Una cuarta crítica, de Entrena Cuesta ${ }^{59}$, sostiene que la tesis unilateralista no ofrece explicaciones razonables para el caso en que el encargo sea asumido por un organismo público. ¿Acaso habría allí un acto imperativo de un ente público a otro? Nuestra respuesta a esta crítica es que la tesis unilateralista solo aborda la naturaleza del intercambio entre el Estado y los integrantes de la comunidad a la que sirve. No se pronuncia sobre la relación jurídica

\footnotetext{
54 Cfr. García 1997, 347 y 348.

55 Martin-Retortillo 1959, 96.

56 Cfr. Sentencia TC Rol N 4.795 (2018).

57 Arrowsmith 1990a, 240.

58 JURISTO 1983, 23.

59 ENTRENA 1957, 49.
} 
entre entes públicos, entre Estados, o entre estos y particulares extranjeros. Probablemente, estos intercambios sí obedecen a figuras convencionales o de coordinación, en atención a que las partes interactúan en un plano de horizontalidad de intereses. Sin embargo, estas figuras son ajenas a los contratos administrativos de subordinación entre el Estado y sus nacionales, objeto de este trabajo.

Una quinta objeción se refiere a la naturaleza del acto adjudicatorio, que no sería de imposición de una carga sino de aceptación del negocio ofrecido por el postulante durante el proceso licitatorio, de forma que viene a cerrar un contrato clásico. Sin embargo, compartimos el contrargumento de López-Muñiz de que la solicitud, oferta o voluntad favorable al encargo manifestada antes de la adjudicación "carece de virtualidad constitutiva del contrato; es solo condición de validez del acto administrativo que lo constituye como tal..." 60 . Semejante voluntad, sostiene este autor, no interviene en la adopción y perfeccionamiento del vínculo más de lo que pueda hacerlo la de un postulante a un empleo público o la del solicitante de una subvención o autorización administrativa. "Nadie dirá con rigor que esos actos administrativos son bilaterales, acordados", pese a que se inician con una manifestación de interés o voluntad favorable del destinatario del acto ${ }^{61}$.

Un sexto contraargumento podría sostener que los contratos administrativos son contratos porque, como explica la doctrina francesa ${ }^{62}$, producen los mismos efectos que los privados: es una ley para las partes, no pueden ser afectados retroactivamente por normativas nuevas, y son de efecto relativo, entre otros. Sin embargo, a nuestro entender, no deben confundirse los efectos del contrato con los efectos de las obligaciones. La identidad de efectos no obedece a que los contratos administrativos gozan de naturaleza contractual, sino a que también son fuente de deberes. El acto administrativo contractual guarda similitud de efectos con el contrato privado porque ambos se rigen por el ius obligationis inter partes, sin perjuicio de que tales obligaciones nacen de un modo diferente: acto versus contrato.

Un razonamiento similar sigue la crítica que identifica los contratos administrativos con los contratos privados de adhesión. Sin embargo, incluso en contratos de prestaciones innegociables, las obligaciones nacen producto de un solo acto bilateral o acuerdo de voluntades, circunstancia que no reconocemos en la relación surgida al amparo un acto administrativo unilateral de ejecutoriedad impropia.

Hemos dejado para el final una crítica que sostiene que el contrato administrativo es contrato porque así lo ha expresado el legislador ${ }^{63}$. Sin desconocer que, efectivamente, el legislador puede atribuir dicha naturaleza a una

\footnotetext{
60 LÓPEZ 2010, 50.

61 ĺdem.

62 LAubadère et al. 1983, 18.

63 ZANOBINI 1958, 236.
} 
relación prestacional con el Estado, ello no sirve para resolver una interrogante dogmática cuyos elementos trascienden con creces la voluntad y nomenclatura del legislador. Semejante recurso al positivismo jurídico para poner fin a una discusión ontológica más profunda es criticado por el propio Mayer mediante el ejemplo del niño que para comer pollo en los días de ayuno eucarístico le dijo: "te bautizo pez"64.

3. Los atributos de los contratos administrativos son naturales al acto administrativo y ajenos al contrato entre partes

Al concebir el contrato público como una relación jurídica originada por un acto unilateral mixto, desaparece la necesidad de calificar sus atributos dogmáticos como "excepcionales". No requieren siquiera de una justificación especial, pues obedecen a cualidades naturales o propias de los actos administrativos; por así decirlo, calzan como el guante a la mano.

En primer lugar, la modificación unilateral del contrato deja de ser especial o sui generis. Semejante potestad es de iure imperii e inherente a los actos administrativos, donde la necesidad de asegurar el bien común exige actuar de modo unilateral ante un cambio de circunstancias que afecte el interés público o privado de la relación, sin perjuicio de las restricciones legales y compensaciones a que haya lugar. En la práctica, la potestas variandi del contrato se reconduce a la revocación parcial y modificación del acto adjudicatorio, que suele contener el estatuto íntegro del intercambio prestacional conforme al principio de autarquía exigido por la Contraloría General de la República ${ }^{65}$.

Es importante enfatizar que la modificación unilateral del contrato se funda en la necesidad de proteger tanto los intereses públicos como privados involucrados. Por así decirlo, la potestas variandi puede ser pro fiscus o pro cives. Lo decimos porque algunas justificaciones doctrinales tienden a ser unidireccionales. Por ejemplo, Jèze sostiene que la variación está fundada en el interés nacional, incluso en casos de compensación al particular por imprevisión, pues así se asegura la continuidad del servicio público ${ }^{66}$. Otros, en cambio, prefieren justificar la variación contractual o el rebus sic stantibus solo para resguardar los intereses del contratista. Ambas posturas son criticables por su parcialidad. Desconocen la preeminencia del bien común como atributo esencial de toda relación pública, lo que justifica la alteración de sus términos para proteger cualquier desequilibrio entre sus elementos indisolubles: el bien de todos y el de cada uno de los integrantes de la comunidad, la distribución eficaz pero equilibrada de las cargas.

Esta idea calza también con los modos de extinción del contrato. Dado que este tiene su origen en un acto administrativo mixto, procede su invalidación con los límites a que haya lugar en relación con el adjudicatario de

\footnotetext{
64 MaYer 1888, 60.

65 Arancibia 2014, 24-26.

66 JèZE 1950, 8.
} 
buena fe. Además, es natural y no "excepcional" que la sentencia de nulidad del acto adjudicatorio no produzca per se el efecto retroactivo del artículo 1687 del Código Civil, pues obedece a un efecto propio de la nulidad de actos administrativos cuyo destinatario está de buena fe.

Asimismo, puesto que el acto adjudicatorio es unilateral, resulta natural su revocación a futuro por razones de mérito, oportunidad o conveniencia del interés público, sin perjuicio de las restricciones y compensaciones que correspondan. Por la misma razón, la resciliación sería improcedente. El término por mutuo acuerdo debe entenderse comprendido entre las causales de revocación del acto.

La naturaleza del contrato público como acto administrativo justifica, además, que el legislador pueda conferir a la autoridad la potestad de sancionar unilateralmente la infracción de deberes del particular, incluyendo la declaración de caducidad en casos graves.

El carácter unilateral del contrato explica también su sometimiento al principio de igualdad ante los bienes y cargas públicas, que es inherente a los actos administrativos regidos por la justicia distributiva y ajeno a los contratos privados regidos por la justicia conmutativa. La unilateralidad determina también la sujeción del contrato a los principios de irretroactividad, intangibilidad de los derechos adquiridos y confianza legítima. En relación con estos últimos, cabe señalar que la adjudicación de la carga pública, que da origen a la relación jurídica, constituye una base de confianza en la estabilidad de los términos de la misma. Por tanto, la necesidad justificada de modificar o de extinguir el contrato hacia futuro por razones de interés público obliga a la Administración a proteger los derechos adquiridos y las expectativas legítimas del contratista de buena fe a través de mecanismos de compensación o transitoriedad del cambio según corresponda.

Como puede observarse, al concebir el contrato administrativo como una relación jurídica originada por un acto administrativo mixto, aquellos atributos que resultaban extraños o excepcionales a la figura contractual pasan a ser intrínsecos, normales, inherentes. Esta es una evidencia adicional de que la calificación de la relación administrativa como "contrato excepcional" es errónea, antinatural y forzada.

\section{Los actos administrativos contractuales surgen del ejercicio de potestades estatales regidas por el derecho público}

De lo dicho se desprende que los actos unilaterales de administración y término del contrato no consisten en facultades contractuales sino en potestades de derecho público. Los actos de imposición y aceptación del encargo público son simplemente presupuestos que habilitan el ejercicio de tales potestades. Esta realidad ha sido reconocida por la doctrina y jurisprudencia española ${ }^{67}$, francesa, italiana y anglosajona.

67 Cfr. Ariño 1968, 266; Boquera 1970, 88; CASSAgne 1999, 70; Juristo 1983, 102 y 103. 
Así, por ejemplo, el Consejo de Estado francés sostuvo en el caso Association Coopérative des Ouvries Paveurs ${ }^{68}$, sobre construcción de alcantarillado, que los poderes de supervisión del contrato no son contractuales sino parte del derecho público general al que se sujeta cualquier persona que se relaciona con el Estado. Por tanto, si el contrato omite mencionarlos no significa de suyo que no existen, y en caso de existir "son inalienables e incondicionales y el gobierno no puede restringirlos por contrato". En igual sentido, Laubadere ${ }^{69}$ en Francia y Cianflone ${ }^{70}$ en Italia califican las órdenes de dirección contractual como poderes administrativos, y Jèze sostiene que el poder de modificación del contrato no emana de este sino del poder regulatorio del Estado ${ }^{71}$. Por su parte, una corte británica sostuvo en el caso Jones v. Swansea City Council" que "el origen último de cada poder [contractual] es ciertamente la ley"73. El mismo criterio ha sido sostenido por la Corte Suprema de Estados Unidos en materia de sanciones contractuales ${ }^{74}$.

En consecuencia, las órdenes de dirección, fiscalización, sanción, modificación, revocación, invalidación y caducidad del contrato administrativo son actos dictados en ejercicio de potestades públicas ${ }^{75}$. Por esta razón, no compartimos las doctrinas que les atribuyen un origen facultativo propio de un contrato privado. Por lo mismo, resulta erróneo atribuir a las sanciones contractuales el carácter de cláusula penal en desmedro de su naturaleza potestativa ${ }^{76}$.

Sin embargo, la mayoría de los autores nacionales citados al inicio de nuestro acápite II.A dan cuenta que el carácter potestativo de estas prerrogativas no es incompatible con la idea del contrato como acuerdo de voluntades. Para ellos, dicho acuerdo habilitaría el ejercicio de poderes legales. Sin embargo, esta posición es contradictoria. Primero, si la celebración del contrato solo "habilita" el ejercicio de poderes legales, entonces la fuente de las prerrogativas no es el contrato sino la ley, y la relación jurídica no es convencional sino legal o estatutaria. Segundo, si el contrato es un acuerdo de voluntades que genera derechos y obligaciones, ¿por qué entonces atribuir un origen normativo distinto a tales facultades? ¿no será más coherente hablar de facultades de origen contractual? Para salvar esta encrucijada, solo

\footnotetext{
68 Ministre de la Guerre v. Association Coopérative des Ouvries Paveurs (1927).

69 Laubadere 1956, 368 y ss.

70 Cianflone 1976, 396.

71 JèZE 1945, 251.

72 Jones v. Swansea City Council (1990).

73 ĺdem; Arrowsmith 1990b, 3 y 4.

74 Así, por ejemplo, en el caso Priebe \& Sons., Inc. v. United States, 332 U.S. 407 (1947), la Corte sostuvo que "no somos remitidos a ningún precepto por el cual el Congreso autorizó la imposición de multas como sanciones a ese programa, ni nosotros encontramos ninguno. No podemos inferir dicho poder". La traducción es nuestra.

75 Ariño 1968, 266; Boquera 1970, 88; CASSAgne 199970.

76 En general, Dictámenes No65.248 (2011), No 8.297 (2012), No21.035 (2012), No34.523 (2013), $N^{\circ} 47.611$ (2013), No 30.003 (2014), N 1765 (2015), No 96.251 (2015), $N^{\circ} 11.961$ (2018) y $N^{\circ} 21.861$ (2018). Espacio y Jardín Ltda. con I. Municipalidad de lquique (2017).
} 
quedaría sostener que se trata de facultades contractuales de origen legal, como aquellas reguladas en el Código Civil respecto de contratos específicos. Sin embargo, semejante explicación envuelve una renuncia al postulado potestativo inicial. No existen diferencias ontológicas entre las facultades legales y las de cláusula contractual, pues ambas son derechos subjetivos. En consecuencia, carecen de naturaleza potestativa. Por lo visto, contrato y potestad son figuras incompatibles entre sí.

Para algunos autores, sin embargo, esta discusión sería irrelevante o estéril porque las prerrogativas unilaterales de un contratista podrían ser inherentes a contratos públicos y privados ${ }^{77}$. No compartimos esta afirmación. Aunque tales prerrogativas existan en cualquier contrato, su carácter potestativo es intrínseco, por su parte, a la relación jurídica del Estado con los particulares. Esta se rige por la regla de oro del derecho público de que el Estado solo puede hacer aquello que está expresamente permitido, no siendo una excepción a este principio el contar con la anuencia del particular. Según la Constitución, los órganos del Estado actúan válidamente dentro de su competencia legal, no siendo posible actuar de facto "ni a aún a pretexto de circunstancias extraordinarias" (art. 7), entre las cuales estaría ciertamente el consentimiento del particular para que el Estado actúe extra vires.

A su vez, dada la naturaleza potestativa de las prerrogativas contractuales, es redundante calificarlas de poderes "exorbitantes". Toda potestad es de suyo exorbitante debido a su unilateralidad, pues constituye una excepción al derecho común de surgimiento de obligaciones por el consentimiento u obrar culposo o doloso del obligado. Puesto que todo contrato administrativo es una relación jurídico-potestativa desde su origen, el Estado nunca ejerce "facultades" sino poderes. Por tanto, la expresión "exorbitante" es siempre superflua o tautológica.

Por otro lado, siendo atribuciones estatales, su ejercicio está sujeto a los requisitos de ius cogens del derecho público. Nos referimos, específicamente, a las exigencias de legalidad, eficacia o procedencia, finalidad, debido proceso, proporcionalidad, igualdad ante el Estado, resguardo de los derechos adquiridos, confianza legítima, y control, entre otros ${ }^{78}$. Como sostiene Mewett, así como estos poderes son de origen extracontractual, lo son también las condiciones para su ejercicio ${ }^{79}$.

\section{a. Legalidad de las potestades contractuales administrativas}

La legalidad de los poderes contractuales exige un análisis más preciso, puesto que ni las normas reglamentarias, ni las administrativas que regulan las bases de licitación, ni el contrato mismo sirven de fuente legítima para su

\footnotetext{
77 JURISTO 1983, ob. cit., en relación con el ius variandi, 178 a 180.

78 Arancibia 2016, 176-189.

79 MeWETT 1958, 226.
} 
otorgamiento ${ }^{80}$, sin perjuicio de su aptitud para precisarlos o de darles mayor publicidad. La Constitución dispone que las potestades públicas -incluidas las contractuales- solo pueden ser conferidas por el legislador (arts. 7 inciso $2^{\circ}$ y 65 inciso $4^{\circ} \mathrm{N}^{\circ} 2$ ). En consecuencia, si el legislador no prevé tales prerrogativas, estas no existen ${ }^{81}$; y si las prevé, estas deben ser ejercidas en los términos exigidos por la ley en cuanto a su qué, quién, por qué, para qué, dónde, cuándo, y cómo.

Esta reserva de ley sale al paso de la doctrina que pretende validar las potestades contractuales creadas por normas administrativas (v. gr. reglamento, bases de licitación) fundada en que la atribución legal de contratar comprende la de establecer otros poderes exorbitantes, en la medida que sean aceptados por el contratista. No compartimos esta afirmación en un régimen constitucional como el nuestro, de competencias legales expresas. La exorbitancia de constituir una relación jurídica de modo unilateral no habilita para afectarla posteriormente del mismo modo. En otras palabras, el poder legal de imponer cargas públicas, sujetas o no a aceptación, no comprende el de modificarlas, sancionar su incumplimiento o terminarlas unilateralmente. Tales prerrogativas son distintas $y$, por tanto, requieren también de poder legal; además, según dijimos, la mera aceptación del particular no bastaría para legitimar actuaciones extra-legem.

Este criterio rige de modo pacífico las relaciones jurídico-administrativas. Por ejemplo, el poder legal de autorizar o subsidiar una actividad no comprende el de fiscalizarla, suspenderla o sancionarla ¿Por qué habría de ser distinto en el caso de las relaciones contractuales administrativas? Por eso que estimamos antijurídica la sanción de incumplimientos contractuales careciendo de poder legal para ello ${ }^{82}$. Lo anterior no se opone a que el contrato pueda contemplar causales de caducidad, solo que, en ausencia de potestad declarativa legal, la Administración solo podrá demandar dicha declaración ante el juez. Esta competencia judicial añade un argumento adicional a la imposibilidad de caducar unilateralmente un contrato mediante una atribución tácita, puesto que la teoría de los poderes implícitos exige, inter alia, que dicho poder no esté atribuido expresamente a otro órgano ${ }^{83}$.

\section{b. Eficacia y debido proceso en las potestades contractuales administrativas}

Por su parte, el requisito de eficacia exige que los actos contractuales unilaterales sean necesarios para satisfacer un interés público calificado por ley ante hechos concretos debidamente acreditados. El órgano no solo puede sino debe actuar ante tales circunstancias, pues se trata de potestades cuyo ejercicio es indisponible, irrenunciable y obligatorio so pena de incurrir en

80 Laubadère et al. 1983, 386; Boquera 1970, 88 y 89.

1 Cfr. Aróstica 2002, 191 a 201.

82 Comadira 2000, 134; Sayagués 2005, 210; Flores 2016, 58.

83 Delpiazzo 2019, párrafos Nº 232 a 235, 264, 275 y 276. 
una omisión antijurídica ${ }^{84}$. Sin embargo, en segundo lugar, en ausencia de tal interés o evidencia, el acto se vuelve desviado, improcedente y, por tanto, arbitrario. De ahí la necesidad de que sea debidamente justificado. Ahora bien, en caso de ser eficaz, queda pendiente revisar su debida proporcionalidad o intensidad en la afectación del particular.

En materia de debido proceso, el ejercicio de poderes contractuales se rige por la garantía constitucional respectiva (art. $19 \mathrm{~N}^{\circ} 3$ inciso $6^{\circ}$ ), la Ley $N^{\circ} 19.880$, y las disposiciones legales y reglamentarias especiales aplicables al contrato. Por esta razón, resultan contrarias a derecho las normativas o bases que permiten la imposición de sanciones o declaraciones de caducidad sin haber considerado los descargos del contratista. Dado que, como explica García de Enterría, la caducidad opera ex re pero la declaración administrativa pertinente es conditio iuris de su efectividad ${ }^{85}$, dicha manifestación potestativa solo podría ser ejercida conforme a un debido proceso que considere estándares básicos de contradictoriedad ${ }^{86}$.

Asimismo, a falta de ley especial, la impugnación de actos administrativos contractuales se rige principalmente por la Constitución, la Ley $N^{\circ} 18.575$, y la Ley $N^{0} 19.880$. Es por esta razón que son antijurídicas aquellas disposiciones que impiden lisa y llanamente la impugnación de actos contractuales ${ }^{87}$.

\section{La justicia rectora de los contratos administrativos es distributiva (no conmutativa)}

La naturaleza del contrato administrativo como acto unilateral determina también la justicia que lo rige. Esta no puede ser otra que la distributiva, que es intrínseca a las relaciones entre el titular del interés del todo y una de sus partes. Siguiendo la idea aristotélica ${ }^{88}$, esta justicia obliga a la autoridad política a distribuir los bienes y cargas necesarias para el bien común de modo justo, dando a cada uno lo que es suyo en relación con los demás ${ }^{89}$.

Siendo esto así, la igualdad que rige el intercambio contractual no se funda en la igualdad de las partes o de sus intereses, propia del derecho

\footnotetext{
84 Coviello 2011, 187.

85 García de Enterría 1950, 105.

86 FLORES 2016, 47 a 79.

87 Véase, por ejemplo, la cláusula vigésima del Contrato de Obra Pública celebrado por la Municipalidad de Providencia y Probinco S.A, de fecha 13 de mayo de 1996, citado en Probinco S.A. con Ilustre Municipalidad de Providencia (2006), c. 5: "En este caso [caducidad] la I.M. dejará sin efecto el contrato en forma unilateral por la simple vía administrativa... En este evento el contratista no tendrá derecho a acción, reclamación o indemnización alguna en contra de la Municipalidad".

88 Aristóteles 1985 y Aristóteles 1988. Serrano 2005, 140-145.

89 Tomás de Aquino lo explica en los siguientes términos, aunque reducido a los bienes: "Como la parte y el todo son en cierto modo una misma cosa, así lo que es del todo es en cierta manera de la parte; y por esto mismo, cuando se distribuye algo de los bienes comunes entre los individuos, recibe cada cual en cierto modo lo que es suyo". De Aouino 2014, 351.
} 
conmutativo privado 90 o internacional ${ }^{91}$, sino en la igualdad de los particulares, contratista y no contratistas, ante el Estado. Las prestaciones de las partes deben ser equivalentes no en razón de la simetría u horizontalidad de sus intereses -que no es tal- sino en virtud del principio distributivo cardinal de igualdad ante los bienes y cargas públicas ${ }^{92}$. De modo que cualquier alteración injusta en las prestaciones del contrato conlleva un privilegio o un gravamen discriminatorio para el contratista en relación con el resto de los integrantes de la comunidad. En otras palabras, la igualdad que rige al contrato administrativo no es "con" sino "ante" el Estado, es proporcional y no aritmética. Evoca la noción matemática y milenaria de Euclides cuando sostiene que "las cosas que son iguales ante la misma cosa [Estado] son también iguales entre ellas"93.

De lo dicho queda en evidencia, a nuestro juicio, el error histórico en que ha incurrido la doctrina en fundar la equivalencia de las prestaciones del contrato administrativo en la justicia conmutativa o en la igualdad de los contratantes $^{94}$, o en instituciones afines como el enriquecimiento sin causa, la buena $\mathrm{fe}^{95}$, el deber de colaboración, o la desaparición de las razones que llevaron a contratar.

Nuevamente, el carácter distributivo de la igualdad que rige al mal Ilamado contrato público permite justificar todos y cada uno de los criterios jurídicos que lo diferencian del contrato privado sin necesidad de calificarlos de excepcionales. Precisamente porque esta relación jurídica se rige por el principio de igualdad ante los bienes y cargas públicas es que se debe adjudicar el contrato por licitación o concurso público objetivo, imparcial y transparente, reestablecer el equilibrio de las prestaciones, evitar alteraciones esenciales del encargo licitado, y compensar al contratista todos los gastos imprevistos e inimputables. En este sentido, la cualidad del rebus sic stantibus, que es de la esencia de toda relación jurídica pública, se funda en la necesidad de asegurar la igualdad distributiva de bienes y cargas para resguardar intereses públicos y privados. El principio del pacta sunt servanda es inaplicable a estas relaciones porque produce una petrificación de las prestaciones que puede perjudicar ambos intereses ante asimetrías sobrevinientes.

La igualdad distributiva como fundamento del pago al contratista es bien explicada por Vázquez de Menchaca ya en el siglo XVI siguiendo, entre otros, a juristas medievales como Baldo: "Si el príncipe dio orden de fortificar

\footnotetext{
90 Aristóteles 1985, 252 a 254. Cfr. Despotopoulos 2005, 11-25. López 2015, 115-181.

91 Véase el caso Société européenne d'études et d'entreprises v. Republique Yugoslavie (1959), en que se aplicó la lex mercatoria, cuyo principio de equivalencia prestacional está fundado en la justicia conmutativa, a un contrato entre el Gobierno de Yugoslavia y una empresa extranjera.

92 Morales 1998, 422 y 423.

93 EuCLIDES 2002, p. 2.

94 De Aquino 2014, 360; Hamilton 1791, 286; Dromi 2009, 535. Dictámenes Nº 17.521 (1982), $\mathrm{N}^{\circ} 26.538$ (1985) y 21.990 (1986).

95 JÈZE 1950, 45.
} 
el castillo o villa de algún ciudadano con el fin de hacer más difícil su conquista ante la amenaza de una guerra... ¿está obligado el ciudadano a efectuarlo a sus propias expensas?... Lo más fundado es, que el súbdito ni está obligado a efectuarlo a sus propias expensas... sino que... debería realizarse a expensas de todo el reino; claro está que el mismo dueño de la villa como uno de los ciudadanos del reino deberá aportar su parte proporcionada a la cuantía de sus bienes..."96.

Sobre la base de lo expuesto, la normativa aplicable a la equivalencia de las prestaciones en el contrato administrativo no es el Código Civil sino la Constitución Política de la República, que dispone la igualdad ante los bienes y cargas públicas en diversos preceptos. Dado el carácter supremo y vinculante de la Carta fundamental respecto de todo el ordenamiento jurídico (art. 6), es posible afirmar que todo contrato administrativo está sujeto al principio constitucional de igualdad distributiva incluso en aquellos casos en que no sea reconocido por la norma inferior que lo rija. En otras palabras, los preceptos pertinentes de la Constitución se integran al estatuto normativo del contrato para garantizar la igualdad distributiva de modo expreso, existan o no mecanismos para facilitar la asimetría prestacional.

En consecuencia, cualquier alteración injustificada del equilibrio financiero del contrato debe ser restaurada por expresa disposición de la Constitución, para efectos de impedir beneficios inmerecidos o cargas públicas desiguales para el contratista. Lo restaurado entonces es un equilibrio distributivo y no sinalagmático. El Código Civil solo podría ser aplicable a estos contratos "en la medida que no contraríen los principios generales de Derecho Administrativo" 97.

\section{Efectos de la justicia distributiva en los contratos administrativos}

Las consecuencias del postulado anterior son dos. Por un lado, el contratista tiene derecho a ser compensado por la mayor onerosidad provocada por alteraciones del equilibrio contractual que le sean inimputables. Por otro, la Administración puede disponer o solicitar al juez, según corresponda, la reducción del precio del contrato ante hechos sobrevinientes que produzcan ganancias injustificadas para el contratista $y$, por tanto, una onerosidad innecesaria para el interés público. Ambas partes, por tanto, quedan sometidas a una relación de igualdad distributiva de bienes y cargas.

Por consiguiente, el contratista administrativo no adquiere un derecho a un precio o utilidad fija, ni siquiera en la hipótesis de suma alzada, sino que a una ecuación fija de costos e ingresos. Si tales costos se ven incrementados por circunstancias sobrevinientes, inimputables, y no reguladas, el contratista tiene derecho a la cobertura de las pérdidas para mantener la ecuación original. Esta misma lógica permite la reducción del precio del contrato, sin afec-

\footnotetext{
96 Vasquez de Menchaca (1564), 176 y 177.

97 Dictamen No 20.165 (1969).
} 
tar los derechos adquiridos o expectativas del contratista, ante la disminución inimputable de los costos del contrato en perjuicio del erario. En ese caso, el ajuste no priva sino que reestablece el coeficiente al que tiene derecho el contratista.

Conforme a la primera proposición, entonces, el contratista tiene derecho, al menos (puede ser más en caso de incumplimiento estatal), al reembolso de los mayores costos que deba asumir para cumplir sus obligaciones ante el desequilibrio financiero provocado por hechos inimputables. Esta compensación mantiene la equivalencia de las prestaciones y evita que el particular asuma gratuitamente una carga de interés común que debería ser soportada por todos ${ }^{98}$. La omisión total o parcial de este deber compensatorio configura una hipótesis de desigualdad ante las cargas públicas prohibida por la Constitución, pues se estaría imponiendo un sacrificio de balde a uno en beneficio de todos. Esta lesión perjudica no solo el interés del particular sino el bien común, que está condicionado al bienestar de todos y "cada uno" de los miembros de la comunidad.

El argumento técnico por el cual la discriminación es arbitraria en estos casos varía según el hecho que produce el desbalance prestacional. a) Si es un acto lícito del Estado, la desigualdad es injusta porque el contratista se ha visto privado del derecho adquirido o de la confianza legítima, según el caso, a obtener una justa retribución por sus inversiones; b) si se trata de un incumplimiento culposo del contrato por parte del Estado, la diferencia es caprichosa porque el responsable de asumir la contravención debe ser el infractor y no el particular solvente; c) si se debe a la realización de trabajos útiles fuera del contrato, la desigualdad es arbitraria porque empobrece al contratista sin causa; d) finalmente, si la circunstancia sobreviniente no es atribuible a ninguna de las partes, el desequilibrio es arbitrario porque debería ser asumido por todos.

En segundo término, la Administración está sujeta al deber de mantener el equilibrio del contrato ante hechos no regulados que aumenten injustificadamente las ganancias del contratista. Nos referimos, por ejemplo, a circunstancias independientes que provoquen una disminución sustancial de los costos y, por tanto, una alteración de la equivalencia de las prestaciones. El Estado, titular del interés público, estaría pagando un sobreprecio por los servicios del particular sin justa causa, pues el beneficio sería ajeno a su eficiencia productiva.

Siguiendo con nuestra idea de reparto justo, la restauración del equilibrio contractual en este caso está fundada en el principio de igualdad ante los bienes públicos (art. 19 N² de la Constitución). El excedente de utilidades para el contratista, causado por el hecho sobreviniente, configura un privilegio inmerecido y, por tanto, arbitrario con respecto a los integrantes de

98 Esta idea está presente en la Sentencia TC Rol Nº 1.254 (2009). 
la comunidad. Es atentatorio del bien común porque privilegia injustamente a uno en detrimento de todos.

Al respecto, es preciso distinguir entre utilidad inmerecida causada por actos del Estado y aquella causada por hechos imprevistos e inimputables a las partes. Si el beneficio proviene de la reducción de costos por potestas variandi o por hecho del príncipe, la mantención de las utilidades originales del contrato produciría un enriquecimiento sin causa. La reducción de utilidades en este caso conlleva una suerte de expropiación del derecho o frustración de expectativas a obtenerlos que se ve compensada por el menor gasto en que incurrirá el contratista, en la medida que sean equivalentes. En cambio, si el desequilibrio beneficioso fue causado por el obrar antijurídico de la autoridad, corresponde que el particular de buena fe se beneficie del excedente conforme a los principios de confianza legítima y de que nadie puede alegar su propia torpeza en perjuicio ajeno. En particular, la pérdida de excedentes debería ser suficientemente justificada y diferida para asegurar adaptación al cambio de circunstancias. Sin embargo, de no ser posible esto último por razones de bien común, la confianza trunca debe ser compensada. Finalmente, si el excedente obtenido por el contratista se debe a circunstancias imprevistas e inimputables a las partes, el enriquecimiento carece de causa y la restauración del equilibrio se rige por la teoría de la imprevisión en derecho público.

En el plano potestativo y procedimental, cabe señalar que la Administración solo podría disponer de una reducción de las utilidades inmerecidas del contratista en la medida que disponga de modo legal y expreso de dicha potestad. Además, la eficacia del acto administrativo modificatorio debe estar sujeta a la aceptación del particular, por obedecer a circunstancias extra-estatutarias. En caso contrario, la Administración solo podrá requerir dicha reducción ante el juez.

Sin perjuicio de todo lo anterior, en los contratos a suma alzada o precio fijo, el sobrecosto o privilegio financiero sobreviniente e inmerecido podría ser asumido legítimamente por el particular en la medida que se deba a una contingencia expresamente prevista en el contrato. En tal caso, el alea de pérdida o ganancia se entiende incluido en el precio del contrato y, por tanto, su ocurrencia perjudica o beneficia al contratista de forma legítima. Sin embargo, esta posibilidad no se extiende al desequilibrio causado por actuaciones antijurídicas de la autoridad, por importar una especie de indemnización anticipada de incumplimiento de obligaciones que atenta en contra del principio de buena fe ${ }^{99}$.

\footnotetext{
99 Obrascon Huarte Lain S.A. Agencia en Chile con Fisco de Chile (2015). Ver también sentencia Constructora Monteverde Ltda. con I. Municipalidad de la Ligua (2013), y Probinco S.A. con Ilustre Municipalidad de Providencia (2006), sobre condonación de dolo futuro.
} 


\section{Conclusiones}

De acuerdo con lo expuesto en este trabajo, es posible destacar las siguientes conclusiones:

1. Los contratos administrativos entre el Estado y los miembros de la comunidad a la que sirve no revisten una naturaleza contractual. Se trata más bien de actos jurídicos unilaterales de asignación de cargas públicas compensadas o mixtos cuyos efectos están sujetos a la aceptación del destinatario. En efecto, la relación jurídica no se perfecciona en virtud de un acuerdo de voluntades sino del acto administrativo que adjudica de dicha carga.

2. Por tanto, la aceptación del encargo por el particular no tiene por función dar origen a una relación jurídica con la Administración sino simplemente que esta produzca efectos; es, por tanto, condición de ejecutoriedad o eficacia y no de existencia de dicha relación. Podemos sostener así que el acto adjudicatorio de la carga es modal, pues sus efectos están sujetos a la condición suspensiva de aceptación del particular. Las obligaciones recíprocas se hacen exigibles, entonces, ante la convergencia de dos actos jurídicos unilaterales: asignación y aceptación de una carga pública compensada.

3. Esta realidad hunde sus raíces en los atributos de la relación jurídica pública que, a diferencia de la privada, solo puede tener su origen en actos unilaterales de distribución de cargas o beneficios al interior de la comunidad. El Estado no puede mantener relaciones jurídicas de conmutatividad e igualdad con aquellos respecto de los cuales es ontológicamente desigual en relación con sus intereses y fines.

4. Al concebir el contrato administrativo como acto unilateral, aquellos atributos que resultaban excepcionales a la figura contractual pasan a ser inherentes. Nos referimos, especialmente, a las llamadas potestades exorbitantes y a los principios de igualdad ante las cargas públicas, derechos adquiridos y confianza legítima.

5. Los actos unilaterales de administración y término del contrato no consisten en facultades contractuales sino en potestades de derecho público. Su ejercicio está sujeto a los requisitos de legalidad, eficacia o procedencia, debido proceso, proporcionalidad, igualdad ante el Estado, esencialidad de los derechos, derechos adquiridos, confianza legítima, y control, entre otros.

6. La naturaleza del contrato administrativo determina también la justicia que lo rige. Esta no puede ser otra que la distributiva, que es la propia de las relaciones entre el titular del interés del todo y una de sus partes surgidas a partir de actos unilaterales, potestativos y distributivos. Esta justicia explica que el contrato administrativo sea concursable, sujeto a bases estrictas y equilibrado financieramente.

7. Las consecuencias de este postulado son dos. Primero, el contratista tiene derecho a ser compensado por la mayor onerosidad provocada por alteraciones del equilibrio contractual que le sean inimputables. Segundo, la Ad- 
ministración puede disponer o solicitar al juez la reducción del precio del contrato ante hechos sobrevinientes que produzcan ganancias injustificadas para el contratista y, por tanto, una onerosidad innecesaria para el interés público.

\section{Bibliografía citada}

ARANCIBIA MATTAR, Jaime (2014). La autarquía de los actos administrativos en la jurisprudencia de la Contraloría General de la República. En: Sото KLoss, Eduardo [coord.], Administración y Derecho. Santiago, Thomson Reuters, pp. 21-33.

Arancibia MatTAR, Jaime (2016). Los puntos de prueba en los litigios de impugnación de actos administrativos. En: Arancibia MatTar, Jaime y Romero, Alejandro [coords.] La Prueba en la Litigación Pública. Santiago, Librotecnia, pp. 161-192.

ARIÑNO ORTIZ, Gaspar (1968). Teoría del equivalente económico en los contratos administrativos, Madrid, Instituto de Estudios Administrativos, 428 pp.

ARIÑO ORTIZ, Gaspar (2007). El enigma del contrato administrativo. Revista de Administración Pública, No 172, enero/abril, pp. 79-102.

Aristóteles (1985). Ética a Nicómaco, libro V (trad. Julio Pallí Bonet), España, Biblioteca Clásica Gredos, 562 pp.

Aristóteles (1988). Política (trad. de Manuela García Valdés), España, Biblioteca Clásica Gredos, $N^{\circ} 116,490 \mathrm{pp}$.

Aróstica Maldonado, Iván (2002). La estabilidad de los contratos administrativos, Revista de Actualidad Jurídica, Nº 6, julio, pp. 191-201.

Arrowsmith, Sue (1990a). Government contracts and Public Law. Legal Studies, Vol. 10, $N^{\circ} 3$, pp. 231-244

Arrowsmith, Sue (1990b). Judicial review and the contractual powers of public authorities. Law Quarterly Review, Vol. 106, april, pp. 277-292.

Bacellar FILHo, R. F. (2014). A incidencia do direito civil nos contratos administrativos. Rodriguez-Arana, Jaime, Jinesta, Ernesto [dirs.], Pernas Garcia, Juan José [coord.], El Derecho Administrativo en perspectiva, Tomo I. Buenos Aires, Ediciones Rap, pp. 53-66.

BARRA, Rodolfo (1989). Los actos administrativos contractuales. Buenos Aires, Editorial Depalma, $200 \mathrm{pp}$.

Bermúdez Soto, Jorge (2014). Derecho Administrativo General. Santiago, Legal Publishing, $794 \mathrm{pp}$.

BLoch, Marc (1968). La sociedad feudal, Madrid, Ediciones Akal, 528 pp.

Bocksang Hola, Gabriel (2015). El nacimiento del derecho administrativo patrio de Chile (1810-1860). Santiago, Thomson Reuters, 904 pp.

Boquera Oliver, José María (1970). Poder administrativo y contrato. Madrid, Escuela de Administración Pública, 109 pp.

CASSAgne, Juan Carlos (1999). El contrato administrativo. Buenos Aires, Abeledo-Perrot, $324 \mathrm{pp}$.

CiAnflone, Antonio (1976). L'appalto di opere pubbliche. Milán, Giuffre, 1097 pp.

Codina Garcia-AndRAde, Xavier (2014). Introducción al régimen inglés de los contratos públicos. Revista de Administración Pública, № 194, mayo-agosto, pp. 411-435.

Comadira, Julio Rodolfo (2000). La licitación pública. Buenos Aires, Editorial Depalma, $210 \mathrm{pp}$.

Cordero Vega, Luis (2015). Lecciones de Derecho Administrativo. Santiago, Thomson Reuters, $786 \mathrm{pp}$.

CoRral TALCIANI, Hernán (2010). La raíz histórica del adagio venire contra factum proprium non valet. En: Corral, Hernán [ed.], Venire contra Factum Proprium. Cuadernos de Extensión Jurídica, Facultad de Derecho, Universidad de los Andes, № 18, pp. 19-33.

Coviello, Pedro (2011). El contrato administrativo: ¿lex inter partes o ius variandi?. Revista de la Facultad de Derecho, Pontificia Universidad Católica del Perú, Nº6, pp. 169-194.

Cuneo, Gilbert. A., y Crowell, Eldon H. (1964). Parallel jurisdiction: if the Court of Claims can, why not the administrative boards. Fordham Law Review $N^{\circ} 33, N^{\circ} 2$, December, pp. 137-172. 
D'ORs, Álvaro (1980). La ley romana acto de magistrado. Nuevos papeles del oficio universitario, Madrid, Ediciones Rialp, pp. 312-330.

De Aouino, Tomás (2014). Suma Teológica, Tratado de la Justicia. Madrid, Edición de Biblioteca de Autores Cristianos, T VIII, 800 pp.

Delpiazzo, Carlos (2019). Contratación administrativa. Montevideo, Fundación de Cultura Universitaria, $1^{\text {a }}$ edición, 776 pp.

Despotopoulos, Constantin (2005). La noción de synallagma en Aristóteles. lus Publicum, $N^{\circ} 14$, pp. 11-25.

DICEY, A. Venn (1915). Introduction to the Study of the Law of the Constitution. Londres, reimpresa, Indianapolis, $8^{a}$ edición, 1982, 436 pp.

Dromi, Roberto (2009). Derecho Administrativo. Buenos Aires, Hispania Libros, $12^{a}$ edición, $1315 \mathrm{pp}$.

Ducci Claro, Carlos (2005). Derecho Civil, Parte General. Santiago, Editorial Jurídica de Chile, $4^{\text {a }}$ edición, 448 pp.

Entrena Cuesta, Rafael (1957). Consideraciones sobre la teoría general de los contratos administrativos. Revista de Administración Pública, Madrid, N²4, pp. 39-74.

Flores RIVAS, Juan Carlos (2016). La caducidad de los contratos administrativos. En: Bermúdez Sото, Jorge [ed.], Perspectivas para la modernización del derecho de la contratación administrativa. Santiago, Escuela de Derecho PUCV, pp. 47-78.

ForstHOFF, Ernst (1969). Traité de droit administratif allemand (trad. Michel Fromont), Bruselas, Etablissements Emile Bruylant, 753 pp.

García de EnterRía, Eduardo (1950). Riesgo y ventura y fuerza mayor en el contrato administrativo. Revista de Administración Pública, Madrid, N² 2, pp. 83-108.

García Pérez, Marta (1997). La naturaleza jurídica de la autorización y la concesión, a propósito de la utilización del dominio público. Anuario da Facultade de Dereito da Universidade da Coruña, N 1, pp. 337-352.

Hamilton, Alexander (1791). The Works of Alexander Hamilton, (Federal Edition), (edit. Henry Cabot Lodge), New York: G.P. Putnam's Sons, 1904, vol 3, 495 pp.

Hauriou, Maurice (1900). Précis de droit administratif et de droit public general. París, P. Larose, $4 \mathrm{a}$ ed., $896 \mathrm{pp}$.

Hauriou, Maurice (1916). Principes de droit public. París, Libraire de la Societé de Recueil Sirey, $2^{\mathrm{a}}$ ed., $828 \mathrm{pp}$.

Hauriou, Maurice (1933). Précis de droit administratif et de droit public. Paris, Dalloz, $12^{\mathrm{a}}$ ed., $1150 \mathrm{pp}$.

HAYNE, The Hon KM (2017). Government contracts and public law. Melbourne University Law Review, Vol. № 41, pp. 155-181.

HiRsChfeld, Julius (1902). Status. Journal of the Society of Comparative Legislation, vol. 4, $\mathrm{N}^{\circ} 2$, pp. 168-172.

HUERGO LORA, Alejandro (1998). Los contratos sobre los actos y las potestades administrativas. Universidad de Oviedo, Civitas, 469 pp.

Jèze, Gaston (1927). Les contrats administratifs de l'Etat, des départements, des communes et des établissements publics. Paris, M. Giard, $257 \mathrm{pp}$.

JèzE, Gaston (1945). Le régime juridique du contrat administratif, Revue du Droit Publique, pp. 251-261.

JèzE, Gastón (1950). Principios generales del derecho administrativo, Tomo V, Teoría General de los Contratos de la Administración, $2^{\mathrm{a}}$ parte, Buenos Aires, Editorial De Palma, 440 pp.

JuRISTO, Rafael (1983). La ejecución del contrato de obra pública, Madrid, Hauser y Menet, $431 \mathrm{pp}$.

KAnemmAn, Daniel, y TVersky, Amos (1974). ,Judgment under Uncertainty: Heuristics and Biases", en: Science, New Series, Vol. 185, No 4157, Sep. 27, pp. 1124-1131.

KELSEN, Hans (1913). Zur Lehre vom öffentlichen Rechtsgeschäft. Archiv des öffentlichen Rechts, No 3, pp. 53-98, y 190-249.

Laband, Paul (1876). Das Staatsrecht des Deutschen Reiches, Tübingen, Laupp, 618 pp. 
Laubadère, A., Moderne, F., y Delvolvé, P. (1983). Traité des contrats administratifs. París, Librairie generale de droit et de jurisprudence, $2^{\mathrm{a}}$ ed., $1144 \mathrm{pp}$.

Laubadere, André de (1956). Traite théorique et pratique des contrats administratifs. París, Librairie générale de droit et de jurisprudence, pp. 1252.

Loo GutiérRez, Martín (2018). Posicionamiento dogmático de la actividad contractual de la Administración del Estado. Revista de Derecho, Pontificia Universidad Católica de Valparaíso, $1^{\text {er }}$ semestre de 2018, pp. 129-155.

López Díaz, Patricia (2015). El principio de equilibrio contractual en el Código Civil chileno y su particular importancia como fundamento de algunas instituciones del moderno derecho de las obligaciones en la dogmática nacional. Revista Chilena de Derecho Privado, $\mathrm{N}^{\circ} 25$, pp. 115-181.

LÓPEZ MUÑIZ, José Luis (1998). Naturaleza de los contratos públicos a la luz del Derecho español, su fundamento y consecuencias. En: CASSAGNE, Juan Carlos [dir.], Derecho Administrativo (Obra colectiva en homenaje al Profesor Miguel S. Marienhoff), Buenos Aires, Abeledo-Perrot, pp. 947-970.

LÓPEZ MUÑIz, José Luis (2010). La causa jurídico-pública de los contratos públicos. Revista de Derecho Público de Venezuela, enero, No 121, pp. 41-65.

Maquiavelo (1998). El Príncipe. San Juan, Edición de la Editorial de la Universidad de Puerto Rico, $8^{a}$ edición, 490 pp.

Martin-Retortillo Baquer, Sebastián (1959). La institución contractual en el derecho administrativo: en torno al problema de igualdad entre las partes. Revista de Administración Pública, Madrid, № 29, pp. 59-102.

MAYER, Otto (1888). Zur Lehre vom öffentlichrechtlichen Vertrage. Archiv des öffentlichen Rechts, Vol. 3, No 1, pp. 3-86.

MEILÁN GIL, José Luis (2011). Una concepción iusadministrativista de los contratos públicos. Derecho PUCP, Revista de la Facultad de Derecho de la Pontificia Universidad Católica del Perú, N66, pp. 223-245.

MeILÁN GIL, José Luis (2015). Un meeting point de los ordenamientos jurídicos sobre contratación pública. Revista de Administración Pública, Madrid, septiembre-diciembre, No 198, pp. 43-73.

MewetT, Alan W. (1958). The theory of government contracts. McGill Law Journal, Vol. 5, pp. 222-246.

Miller, Arthur S. (1955). Government Contracts and Social Control: A Preliminary Inquiry. Virginia Law Review, Vol. 41, No 1, pp. 27-58.

Moraga Klenner, Claudio (2019). Contratación Administrativa. Santiago, Editorial Jurídica de Chile, 325 pp.

Morales ESPINOZA, Baltazar (1998). Teoría de la imprevisión. Revista de Derecho, Universidad de Concepción, año LXVI, N²03, pp. 421-427.

Oelckers Camus, Osvaldo (1979). En torno al concepto de contrato administrativo. Revista de Derecho, Pontificia Universidad Católica de Valparaíso, № 3, pp. 135-160.

Pantoja Bauzá, Rolando (1994). El Derecho Administrativo: Clasicismo y Modernidad. Santiago, Editorial Jurídica de Chile, 280 pp.

Parada VÁsquez, Ramón (1963). Los orígenes del contrato administrativo en el derecho español Sevilla, Instituto García Oviedo, Universidad de Sevilla, 232 pp.

RanellettI, Oreste (1945). Teoria degli atti amministrativi speciali. Milán, Giuffré, 156 pp.

Real Academia Española (2001). Diccionario de la lengua española (22.a ed.). Disponible en: http://www.rae.es/rae.html [fecha de consulta: 28 octubre 2019].

Sayagués Laso, Enrique (2005). La Licitación Pública. Montevideo, Editorial B de f., 211 pp.

SerRano, Enrique (2005). La teoría aristotélica de la justicia. Isonomía, Instituto Tecnológico Autónomo de México, abril, N²2, pp. 123-160.

Silva Cimma, Enrique (2001). Derecho Administrativo Chileno y Comparado, Actos, Contratos y Bienes. Santiago, Editorial Jurídica de Chile, $336 \mathrm{pp}$.

Sото KLoss, Eduardo (2012). Derecho Administrativo Temas Fundamentales. Santiago, Thomson Reuters, $3^{\text {a }}$ edición, 966 pp. 
SuÁREZ, Francisco (1968). Tratado de las Leyes y de Dios Legislador (versión en español por José Ramón Eguillor Muniozguren), Volumen V, Libro VIII, Capítulo 37, Madrid, Instituto de Estudios Políticos, 1074 pp.

Trowbridge vom Baur, F. (1967). Differences between Commercial Contracts and Government Contracts. American Bar Association Journal, 53, N 3, March, pp. 247-251.

Valdivia Olivares, José Miguel (2018). Manual de Derecho Administrativo. Santiago, Tirant Lo Blanch, 448 pp.

VAsquez de MenchacA, Fernando (1932[1564]). Controversias fundamentales, Libro Primero (trad. Fidel Rodríguez Alcalde). Valladolid, Talleres Tipográficos Cuesta, 367 pp.

WEIL, Prosper (2016). La crisis del criterio de contrato administrativo. Revista de Derecho Público, Universidad de Chile, vol. 1986, №39-40, pp. 163-184.

ZANobinI, Guido (1958). Corso di diritto amministrativo. Milano, Dott. A. Giuffrè, $8^{a}$ edición, T VIII, 423 pp.

\section{Normas citadas}

Constitución Política de la República. Diario Oficial, 21 octubre 1980.

Código Civil. Diario Oficial, 16 mayo 2000.

Ley N ${ }^{\circ} 18.575$, Orgánica Constitucional de bases generales de la administración del Estado. Diario Oficial, 25 diciembre 1986.

Ley $N^{\circ} 19.880$, establece bases de los procedimientos administrativos que rigen los actos de los órganos de la administración del Estado. Diario Oficial, 29 mayo 2003.

Ley $N^{\circ} 19.886$, de bases sobre contratos administrativos de suministro y prestación de servicios. Diario Oficial, 30 julio 2003.

\section{Jurisprudencia citada}

Francisco Ovalle, sobre construcción de los almacenes fiscales de Valparaíso en 1856, Consejo de Estado, 3 de julio de 1856, en Archivo Nacional Consejo de Estado, Vol. 104, fojas 167 a 180.

Cooke v. United States, 91 U. S. 389 (1875).

Contributors to Pennsylvania Hospital v. Philadelphia, 245 U.S. 20 (1917).

Rederiaktiebolaget Amphitrite v. The King, seguido ante la Kings Bench Division, Sentencia de 27 de julio de 1921, The Law Times, Vol. 126, p. 65.

Ministre de la Guerre v. Association Coopérative des Ouvries Paveurs, sentencia de 15 de agosto de 1927, R. 966.

Priebe \& Sons., Inc. v. United States, 332 U.S. 407 (1947).

Société européenne d'études et d'entreprises v. Republique Yugoslavie, Journal du Droit International, Tomo No 86, 1959, p. 1074.

Dictamen N 20.165 (1969). Contraloría General de la República, 7 de abril de 1969.

R. v. Barnsley Metropolitan Borough Council, ex p. Hook, [1976] 1 W.L.R. 1052 (C.A.).

Cannock Chase D. C. v. Kelly [1978] 1 W.L.R. 1 (C.A.).

R. v. Basildon District Council, ex p. Brown (1981) 79 L.G.R. 655 (C.A.).

Dictamen N 1.752 (1982). Contraloría General de la República, 15 de enero de 1982.

Dictamen Nº 26.538 (1985). Contraloría General de la República, 18 de noviembre de 1985.

R. v. Wear Valley District Council, ex p. Binks [1985] 2 All E.R. 699 (Q.B.).

Dictamen N 21.990 (1986). Contraloría General de la República, 16 de septiembre de 1986.

R. v. Lewisham Borough Council, ex p. Shell U.K. Ltd. [1988] 1 All E.R. 938 (Q.B.).

R.v. Enfield London Borough Council, ex p. Unwin [1989] C.O.D. 466.

Jones v. Swansea City Council [1990] 1 W.L.R. 54.

Dictamen No 46.532 (2000). Contraloría General de la República, 4 de diciembre de 2000.

Probinco S.A. con Ilustre Municipalidad de Providencia (2006). Corte Suprema, 30 mayo 2006.

Dictamen N 30.070 (2008). Contraloría General de la República, 1 de julio de 2008.

Sentencia TC Rol No 1.254 (2009). Tribunal Constitucional, 29 julio 2009. 
Alfredo León Ramírez con llustre Municipalidad de Quillota (2009). Corte Suprema, 8 septiembre 2009.

Dictamen N 60.656 (2011). Contraloría General de la República, 26 de septiembre de 2011.

Dictamen N 65.248 (2011). Contraloría General de la República, 17 de octubre de 2011.

Dictamen N 8.297 (2012). Contraloría General de la República, 10 de febrero de 2012.

Dictamen N²1.035 (2012). Contraloría General de la República, 12 de abril de 2012.

Dictamen Nº 34.523 (2013). Contraloría General de la República, 4 de junio de 2013.

Dictamen No 47.611 (2013). Contraloría General de la República, 26 de julio de 2013.

Constructora Monteverde Ltda. con I. Municipalidad de la Ligua (2013). Corte Suprema, 26 septiembre 2013.

Dictamen N 30.003 (2014). Contraloría General de la República, 29 de abril 2014.

Fisco de Chile con Dorr Zegers María Teresa y otros (2014). Corte Suprema, 30 octubre 2014.

Dictamen N 1.765 (2015). Contraloría General de la República, 9 de enero 2015.

Dictamen N³0.871 (2016). Contraloría General de la República, 25 de abril de 2016.

Obrascon Huarte Lain S.A. Agencia en Chile con Fisco de Chile (2015). Corte Suprema, 30 agosto 2016.

Dictamen N 96.251(2015). Contraloría General de la República, 3 de diciembre de 2015.

Empresa de Servicios Himce Limitada con Municipalidad de Hualqui (2017). Corte Suprema, 16 de abril de 2018.

Espacio y Jardín Ltda. con Ilustre Municipalidad de Iquique (2017). Corte Suprema, 1 febrero de 2017.

Fisco de Chile con Vicente Aresti López y otros (2018). Corte Suprema, 15 enero 2018.

Dictamen N 1.196 (2018). Contraloría General de la República, 10 de mayo de 2018.

Dictamen N²1.861(2018). Contraloría General de la República, 21 de agosto de 2018.

Sentencia TC Rol No 4.795 (2018). Tribunal constitucional, 2 agosto 2019. 